\title{
A Case with a Remarkable Prolongation of Blood Coagulation :- Pseudohemophilia Hepatica (Frank). The First Case Published under This Name in Japan, in spite of Possibly Frequent Occurrence in the Newborn Age.
}

\author{
sgth Hematological Paper. \\ By \\ Tamotsu Suzuki and Shiu Sato. \\ (鍮 水 保) (佐藤 秀) \\ (From the Department of Pediatrics, Faculty of Medicine, Tohoku \\ Imperial University, Sendai. Director: Prof. A. Sato.)
}

\section{Introduction.}

A remarkable prolongation of clotting time occurs most frequently in hemophiliac blood, and it is quite fitting to take a male patient with remarkable delay of blood coagulation for hemophilia. Now, a boy was admitted into our Department in October in 1935. He had a profuse wound bleeding and was sent by a doctor to us under the possible diagnosis of hemophilia. We considered this diagnosis as correct when blood coagulation of this patient was examined, but later we found that the diagnosis was not right, and concluded that this case would in all probability be "Pseudohemophilia hepatica (Frank $\left.{ }^{1}\right)$." This report is, we believe, very important, because to the best of our knowledge we have no report on pseudohemophilia hepatica in our country, and we wish to draw attention to this.

Case Report.

Patient: J. Shiraishi, a boy aged 36 days, native in Sendai (on Oct.9th, 1935).

Paternal side-Grandfather had a venereal disease in his anamnesis and died from heart disease. Grandmother is well.

1) E. Fra n k, "Die Krankheiten des Blutes und der blutbildenden Organe" von Schitten helm, Berlin 1925, 2, 445 . 
Maternal side-Grandfather and grandmother are well. An elder brother of the mother died from severe blood expectoration at the age of 19 years. The third son of an elder sister of the mother had purpura on the whole body at the age of 2 years, but later he has shown no hemorrhagic diathesis and is well, now 7 years old. We examined the clotting time, the bleeding time and the blood picture of this boy which were all normal. There is no abnormality on his body, and it is indubitable that he is not hemophiliac.

Parents-Parents are well and their blood serum are negative to W as s e rmann's reaction. Father suffered from nephritis when 4 years old.

Mother had a miscarriage in consequence of overwork, according to her.

Patient has no brother or sister.

History : Patient was easily delivered in the maturity. His body weight at the birth was about three kilograms. He had no bleeding from the umbilical cord. He was nursed with mother's milk.

Jaundice occurred four days after the birth, which showed an exacerbation about one month later. On 8th October, a few days after the exacerbation was found by his mother, a purpura of thumb tip size on the middle of tibial edge of his right leg. The next day he vomited milk at about 7 A.M. and blood at about 9 A.M., and excreted tar like faeces soon after. He became remarkably pale and cried frequently. He was subcutaneously injected with a cardiac on the left breast by a physician, and then a bleeding from the site of the injection began and would not stop till the evening. Blood vomiting occurred again and soon the baby was admitted to our Department at about 8 P.M.. The possible diagnosis of the physician was as stated above hemophilia. Soon after the admission, the patient vomited fresh blood once more.

Examination at the admission: The baby is in bad temper and has no appetite. The consciousness is almost lost. The face is pallid and intensely jaundiced. The pulse is somewhat weak and 120 per minute. He has a temperature of $36.7^{\circ} \mathrm{C}$. The skin is pale and jaundiced, but he has no exanthema, no oedema. A purpura of thumb tip size is seen on the middle of the tibial edge of the right leg. The site of the injection below the clavicle on the left breast is still bleeding. The head has no abnormity. The bulbar conjunctiva is jaundiced and the palpebral conjunctiva is anemic. The mucous membranes of mouth and pharynx are anemic, but no bleeding spot is seen. The heart has no murmurs and lungs and normal on percussion and auscultation. The abdomen is slightly distended. The liver is enlarged, though normal in consistence and of smooth surface, and its rather sharp edge is palpable somewhere about one and half transverse fingers with below the right costal margin. The spleen is not palpable. All of the external lymphatic glands are not palpable either. The knee jerk is equal in its intensity oh both sides, but slightly weak in response. No pathological reflex.

Urine: Clearly transparent, yellow. Protein $(-)$, diazo (-), blood (-), bilirubin $(-)$ and urobilinogen $(-)$. In the deposit, a few epithelial cells of the bladder and a few white and red blood cells are microscopically seen.

Faeces: Tar like. 
Vomited mass: Fresh blood.

Blood examination: Blood was examined four times and the results are shown in Table II. Murata's reaction of serum for syphilis is negative.

Course: Cf. Fig. and Table 1.

Fig. Course.

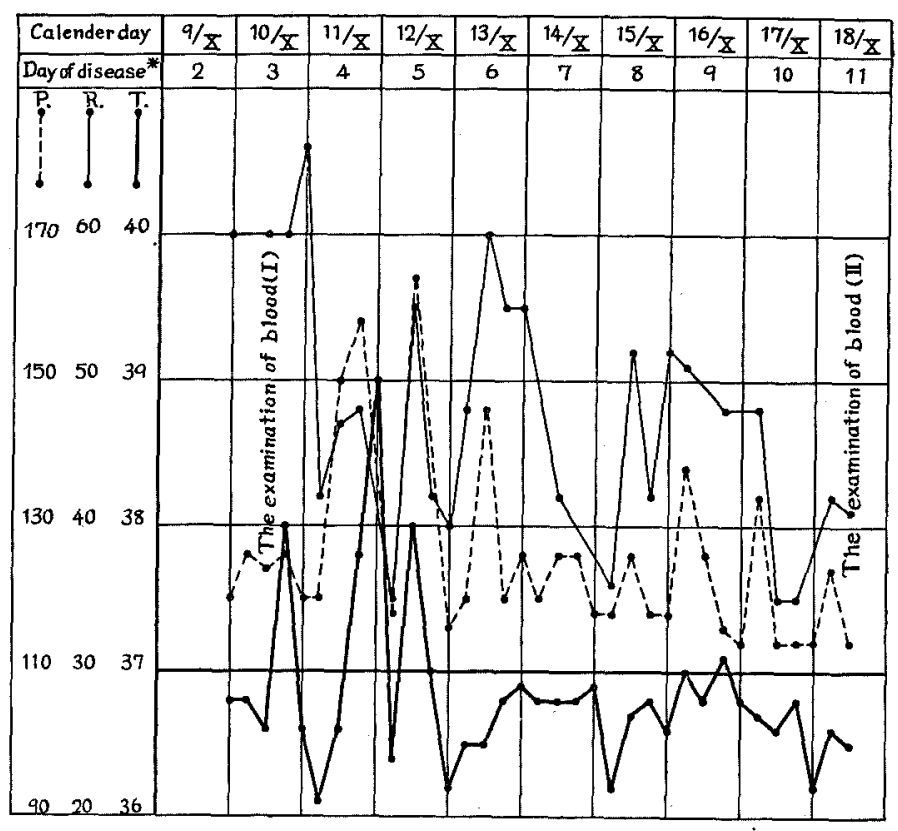

Discussion.

As stated above, our first probable diagnosis was, as it might seem natural, hemophilia. But the notable prolongation of coagulation very soon ceased to be pronounced and coagulation was restored to the normal. The patient had no hemorrhage in any articular cavity, which is very common in the case of hemophilia. "Hemophilia" was thus to be dropped.

Next we thought of congenital hemolytic anemia on account of the anemia and the icterus. But, then no small or spherical erythrocyte was seen, not to speak of an increase of them. Besides, the reticulocyte count was not large in spite of an examination at the recovering stage of anemia; and the erythrocyte resistance to hypotonic $\mathrm{NaCl}$ 
solutions was normal. Thus, none of the trias of symptoms peculiar for the congenital hemolytic anemia asserted by $\mathrm{Ch}$ a uffa $\mathrm{rd}^{2}$ was present, nor was an enlargement of the spleen observed, while the time of blood clotting was intensely prolonged. Congenital hemolytic anemia was thus excluded.

Purpura hemorrhagica was excluded, because of the normal blood platelet count, the normal bleeding time and the intensely delayed blood coagulation.

Henoch's purpura was excluded of course.

There was no considering of infantile scurvy; he was almost a new born and breast fed.

The hemorrhagic diathese secondary to a poisoning was very unnatural in this case. The little patient had not taken any medicine at all yet.

On the ground of the blood picture and the very favourable course of this patient, it will be easily seen that there was no special blood disease with this infant, except the secondary anemia caused by a profuse bleeding.

Now, it is a very essential question what caused the hemorrhagic diathesis accompanied by a very intensely delayed coagulation of blood with the secondary anemia as its sequela. Let us consider pseudohemophilia hepatica (Frank) in this case.

1. In this case icterus neonatorum continued for a long time and showed an exacerbation before the occurrence of hemorrhagic diathesis, so that we have a fair reason to believe that there was a disorder of the liver function.

2. By an administration of yakriton, ${ }^{* *}$ the detoxicating hormone of the liver, all symptoms, especially jaundice, disappeared rapidly, so we can believe that the liver function was restored more or less to the normal by the hormone and that the patient was recovered.

3. As to the non-hemophiliac disease with a hemophilia like prolongation of the coagulation time, there are two diseases to be taken into consideration. One is pseudohemophilia hepatica (Frank), and the other is fibrinopenia described at first by Rabe and Salomon ${ }^{3}$ ) and later by Opitz and $\mathrm{Frei}^{4}$. But fibrinopenia is perhaps out of the

2) A. Chauffard, La Sem. méd., 1909, No. 8, 95.

** Cf. A. S a to, Osaka Iji Shinsi, 1985, 6, 1.

3) F. R a be and E. S a lo m o n, Dtsch. Arch. f. kl. Med., 1920, 132, 240.

4) H. Opitz and M. Frei, Jahrb. f. Kinderheilk., 1921, 94, 374. 
TAble 1.

\begin{tabular}{|c|c|c|c|c|c|c|}
\hline \multicolumn{2}{|c|}{ Calender day } & \multicolumn{2}{|r|}{$9 / X$} & $10 / X$ & $11 / \mathrm{X}$ & $12 / \mathrm{X}$ \\
\hline \multicolumn{2}{|c|}{$\begin{array}{l}\text { Day* of } \\
\text { disease }\end{array}$} & \multicolumn{2}{|r|}{2} & 3 & 4 & 5 \\
\hline \multicolumn{2}{|c|}{$\begin{array}{l}\text { Yakriton } \\
\text { (R.A.U.) }\end{array}$} & \multicolumn{2}{|r|}{ - } & $1 / 5$ & Ditto & Ditto \\
\hline \multicolumn{2}{|c|}{ Oryzanin (c.c.) } & \multicolumn{2}{|r|}{ 一 } & 1.0 & Ditto & Ditto \\
\hline \multicolumn{2}{|c|}{$\begin{array}{l}\text { Blood trans- } \\
\text { fusion (c.c.) } \\
\text { (into vein) } \\
\end{array}$} & \multicolumn{2}{|r|}{ - } & $\begin{array}{l}10.0 \times 1 \\
20.0 \times 2\end{array}$ & $20.0 \times 1$ & - \\
\hline \multirow{2}{*}{$\begin{array}{l}\text { Vomit- } \\
\text { ing }\end{array}$} & Blood & \multirow{4}{*}{ 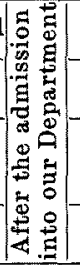 } & 3 & 0 & 0 & 0 \\
\hline & Milk & & 0 & $\mathbf{2}$ & 1 & 0 \\
\hline \multicolumn{2}{|c|}{ Faeces } & & $\begin{array}{c}1 \\
(\operatorname{tar} \text { like) }\end{array}$ & $\begin{array}{c}3 \\
\text { (soft) }\end{array}$ & $\begin{array}{c}3 \\
\text { (mucous) }\end{array}$ & $\begin{array}{c}3 \\
\text { (mucous) }\end{array}$ \\
\hline \multicolumn{2}{|c|}{$\begin{array}{c}\text { Frequency } \\
\text { of urine }\end{array}$} & & 4 & 6 & 5 & 7 \\
\hline \multicolumn{2}{|c|}{$\begin{array}{c}\text { A purpura on } \\
\text { the middle part } \\
\text { of the tibial } \\
\text { edge of right } \\
\text { leg }\end{array}$} & \multicolumn{2}{|c|}{$\begin{array}{l}\text { Thumb tip } \\
\text { size, distictly } \\
\text { purple }\end{array}$} & Ditto & Ditto & Ditto \\
\hline \multicolumn{2}{|c|}{$\begin{array}{l}\text { Degree of } \\
\text { pallidness }\end{array}$} & \multicolumn{2}{|c|}{ Very distinct } & Ditto & Ditto & Ditto \\
\hline \multicolumn{2}{|c|}{$\begin{array}{l}\text { Degree of } \\
\text { jaundice }\end{array}$} & \multicolumn{2}{|c|}{ Very distinct } & Ditto & Ditto & Ditto \\
\hline \multicolumn{2}{|c|}{$\begin{array}{l}\text { Enlargement } \\
\text { of the liver }\end{array}$} & \multicolumn{2}{|c|}{$\begin{array}{l}\text { About one and } \\
\text { half transverse } \\
\text { finger's width } \\
\text { below the right } \\
\text { costal arch, } \\
\text { surface smooth }\end{array}$} & Ditto & Ditto & Ditto \\
\hline \multicolumn{2}{|c|}{ Humour } & \multicolumn{2}{|c|}{$\begin{array}{c}\text { Stuporous, } \\
\text { consciousness } \\
\text { almost lost }\end{array}$} & Ditto & Ditto & Somewhat better \\
\hline \multicolumn{2}{|c|}{ Appetite } & \multicolumn{2}{|r|}{ Bad } & Ditto & $\begin{array}{l}\text { Better at } \\
\text { night }\end{array}$ & Somewhat better \\
\hline \multicolumn{2}{|c|}{ Remarks } & \multicolumn{2}{|c|}{ 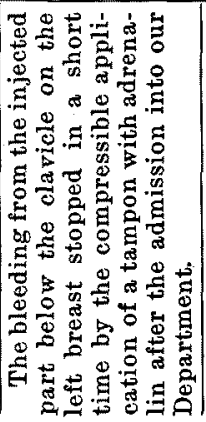 } & 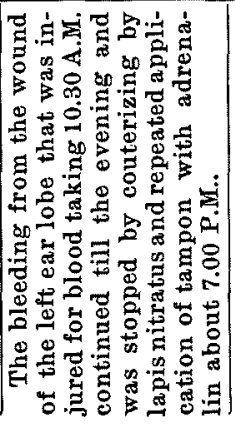 & 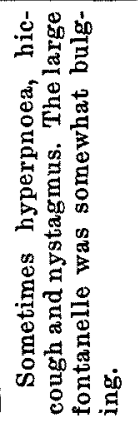 & 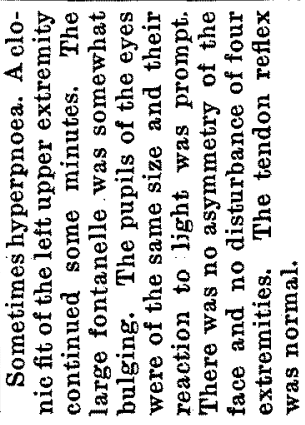 \\
\hline
\end{tabular}

* The day on which purpura was for the first time noted as the 1 st day of disease. 
Course.

\begin{tabular}{|c|c|c|c|c|c|}
\hline $13 / X$ & $14 / \mathrm{X}$ & $15 / X$ & $16 / X$ & $17 / X$ & $18 / \mathrm{X}$ \\
\hline 6 & 7 & 8 & 9 & 10 & 11 \\
\hline Ditto & Ditto & Ditto & Ditto & Ditto & Ditto \\
\hline Ditto & Ditto & Ditto & Ditto & - & 一 \\
\hline - & - & - & - & - & - \\
\hline $\mathbf{0}$ & 0 & 0 & 0 & 0 & 0 \\
\hline 0 & 2 & 0 & 0 & 0 & 0 \\
\hline $\begin{array}{c}2 \\
\text { (mucous) }\end{array}$ & $\begin{array}{c}5 \\
\text { (mucous and } \\
\text { granular) }\end{array}$ & $\begin{array}{c}4 \\
\text { (mucous and } \\
\text { granular) }\end{array}$ & $\begin{array}{c}2 \\
\text { (mucous and } \\
\text { granular) }\end{array}$ & $\begin{array}{c}2 \\
\text { (mucous and } \\
\text { granular) }\end{array}$ & - \\
\hline 6 & 10 & 10 & 13 & 10 & - \\
\hline Ditto & $\begin{array}{l}\text { Thumb tip size, } \\
\text { somewhat faded }\end{array}$ & Ditto & Ditto & Ditto & Ditto \\
\hline $\begin{array}{l}\text { Somewhat } \\
\text { recovered }\end{array}$ & Ditto & $\begin{array}{c}\text { Much } \\
\text { recovered }\end{array}$ & $\begin{array}{l}\text { Almost no } \\
\text { pallidness }\end{array}$ & $\begin{array}{c}\text { No } \\
\text { pallidness }\end{array}$ & - \\
\hline $\begin{array}{c}\text { Somewhat } \\
\text { faded }\end{array}$ & Ditto & Ditto & Much faded & Ditto & Almost faded \\
\hline Ditto & $\begin{array}{l}\text { About one trans- } \\
\text { verse finger's } \\
\text { width below the } \\
\text { right costal arch, } \\
\text { surface smooth }\end{array}$ & Ditto & Ditto & Ditto & Ditto \\
\hline $\begin{array}{c}\text { More or } \\
\text { less } \\
\text { unconscious }\end{array}$ & Somewhat better & Good & Good & Good & Good \\
\hline Ditto & Ditto & Good & Good & Good & Good \\
\hline 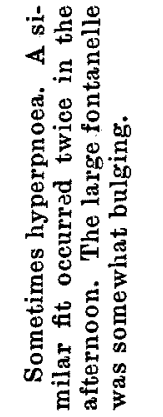 & 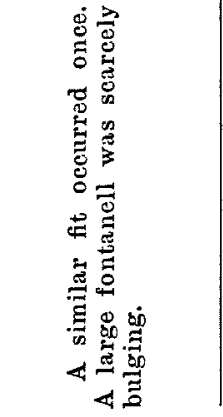 & 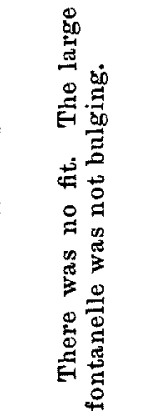 & & & \\
\hline
\end{tabular}




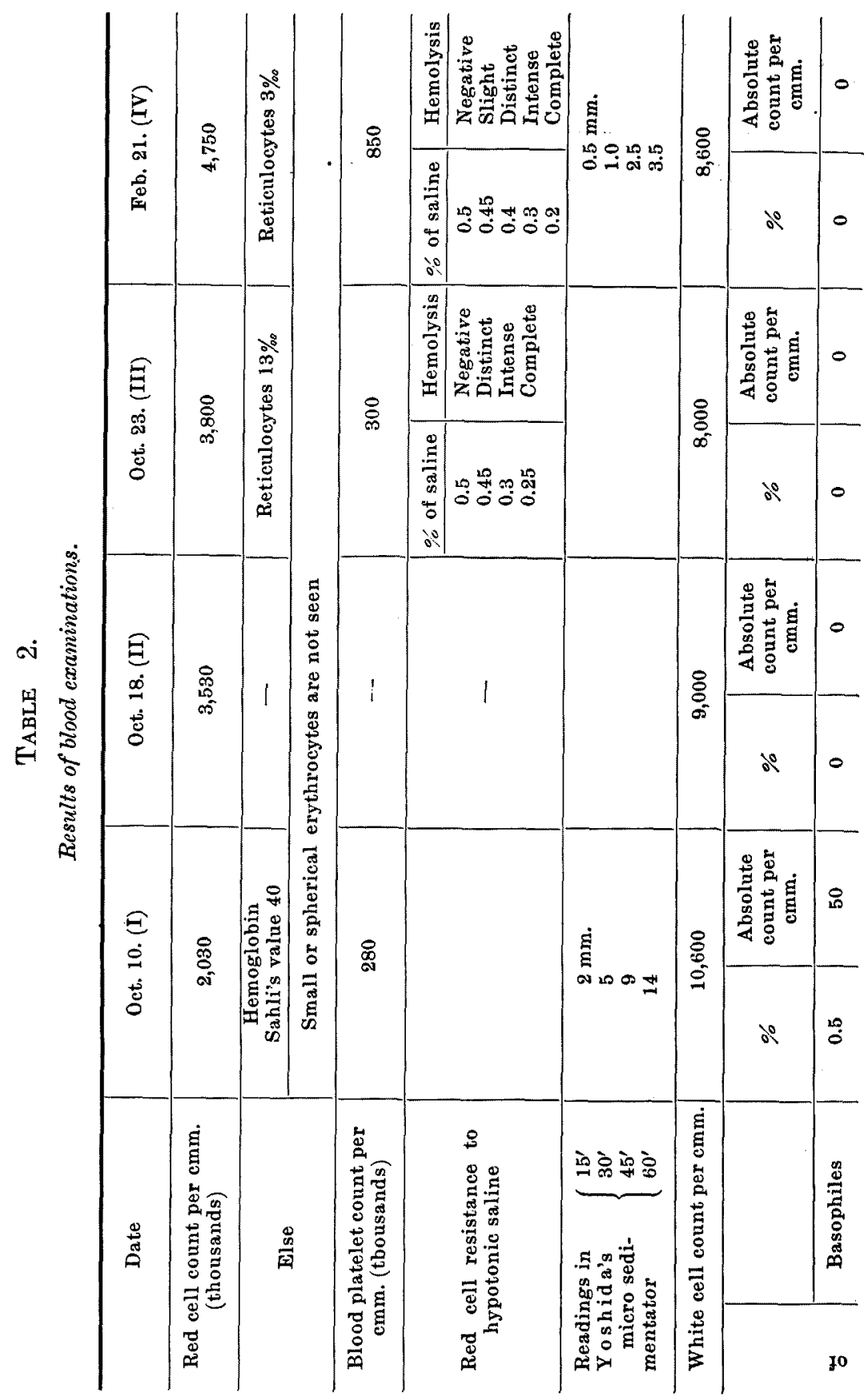




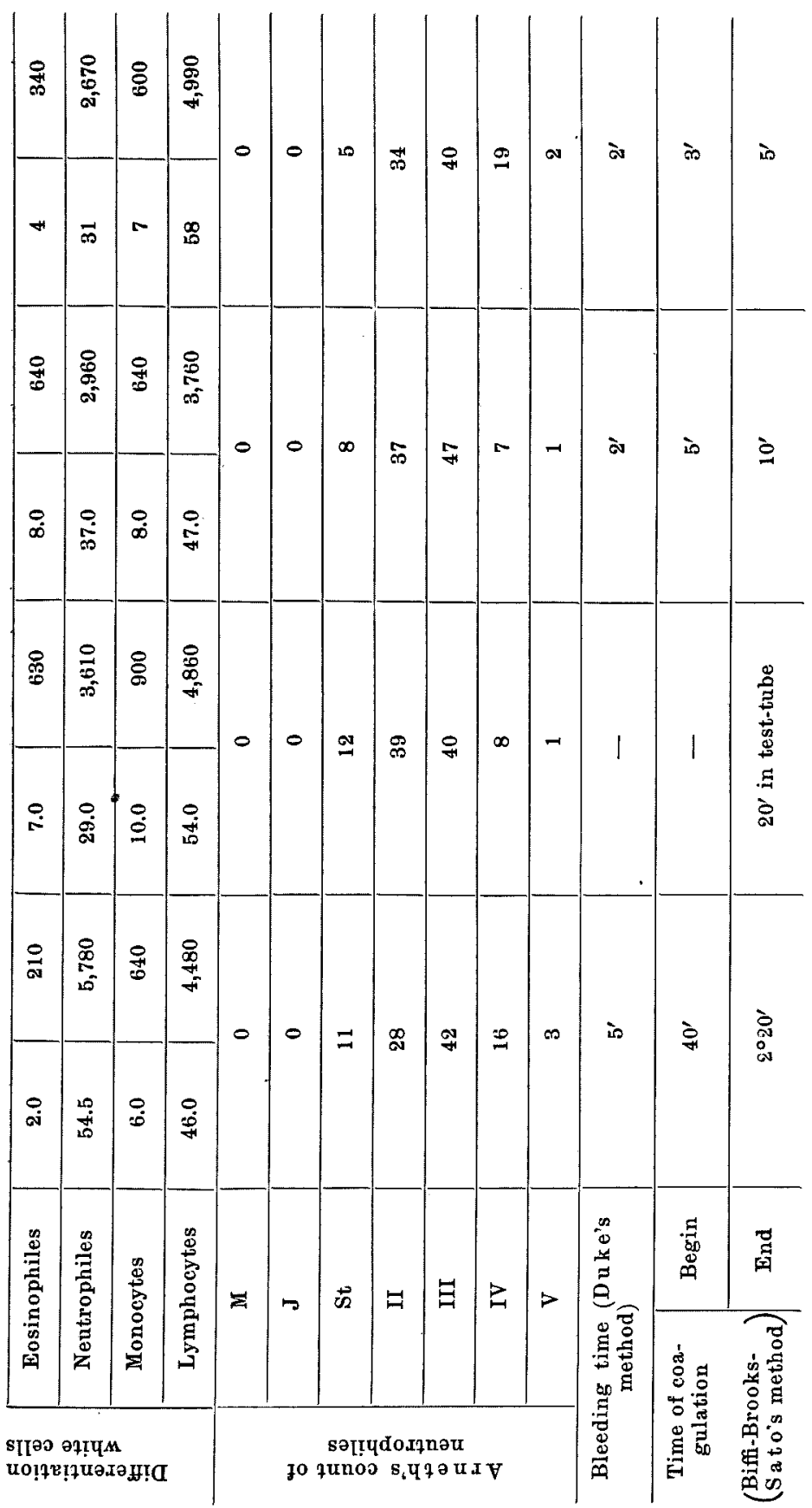


question. There are only two cases $\ddagger$ of fibrinopenia hitherto reported. It seems to be characteristic of the disease that blood will not coagulate. In one case of the two reported it did not coagulate as long as 4 days and in the other as long as 8 days. In our case blood coagulated in vitro in two hours and twenty minutes.

In our case, the time for blood coagulation was restored to the normal before the jaundice faded away completely, and the prolonged coagulation was probably not due to the presence of jaundice. And probably it is needless to add, from the experiments of Morawitz and Bierich ${ }^{5}$ and Petré ${ }^{6)}$, that the delay of blood clotting observed in cases of liver diseases is not due to a hindrance of blood clotting caused by bile acids in blood.

Furthermore, the fact that the red cell sedimentation value did not run parallel to the grade of anemia in our case, led us to suppose that there might have been a want of fibrinogen in it.

Admitting that the dysfunction of liver produced experimentally in animals results in a disturbance of blood coagulation due to a disappearance of fibrinogen, Frank ${ }^{1)}$ says that this fact may not be applied to the pathology of liver in human beings. And further, according to the opinions of Morawitz and Bierich ${ }^{5)}$ and of Schultz and Scheffer, ${ }^{7)}$ the want of fibrinogen is not an important cause of the prolongation of blood coagulation in a case of hepatic dysfunction.

Unfortunately we had no opportunity to perform an exhaustive examination of the mechanism of a prolonged blood coagulation in the present case.

Of course we do not claim that this case of ours is the very first case of pseudohemophilia hepatica (Frank) ever existent in Japan. Such a case with remarkable prolongation of blood coagulation due to hepatic dysfunction must, we think, be of possibly frequent occurrence among a large number of newborn patients with the diagnosis of melaena neonatorum or with a hemorrhagic diathesis. And the administration of yakriton, the liver hormon, may be a rational treatment in such a case.

$\ddagger$ Cf. further, R. G. M a c f a r la ne, Lancet, 1938, 234, 309. (Blood did not coagulate in vitro during 3 weeks in a boy of 16 months).

5) P. Morawitz and R. Bierich, Arch. f. Exp. Pathol. u. Pharmakol, 1907, 56, 115.

6) G. Petrén, Beitr. z. klin. Chirurg., 1920, 120, 501.

7) W. Schultz and W. Scheffer, Berl. kl. Wscher., 1921, 58, 789. 


\section{Conclusions.}

We have had an opportunity to observe, in a case of a baby aged 36 days, a severe hemorrhagic diathesis with remarkable prolongation of blood coagulation developed after a rather long continuation and an exacerbation of icterus neonatorum, and our final diagnosis was pseudohemophilia hepatica (Frank). In this case yakriton was, we believe, a very efficacious factor for making the coagulation restore to the normal. 